\title{
Hugh Clegg: recollections of a great editor
}

\author{
Austin Bradford Hill
} Ambleside, Cumbria LA22 0JQ Sir Austin Bradford Hill, FRS, DSC, emeritus professor of medical statistics

BrMed J 1990;301:752-5
Balla Wray Nursing Home,

In writing these memories of my friendship with Hugh Clegg I must of course be autobiographical. I do not remember when I first met him, and I shall deliberately go back to the years when I am sure I had not-the mid-1920s.

While convalescing after my long attack of tuberculosis I had read economics, and I took the London University degree in that subject in 1922. I then got a grant from the Medical Research Council. Barred from clinical medicine, I determined to make a life in preventive medicine. For medical reading I naturally turned to the Lancet - the $B M F$, as Hugh once said to me, "spent half the year preparing for the BMA's annual meeting and half the year reporting it and neither was worth the effort or the paper on which it was printed."

\section{From the Lancet to the $B M F$}

At the Lancet, under Sir Squire Sprigge, I became a close friend of Mrs Pam Kettle, and it was she who asked me to write the articles in the Lancet in 1937 to persuade the medical profession to appreciate statistics and the numerical approach. I wrote many annotations and editorials, and one of these was the cause of my switching from the Lancet to the BMF. I had a minor squabble with $\mathrm{Sir}$ Theodore Fox, who had become editor of the Lancet. My memory is that it was over the observations of Gregg in Australia on the effects of rubella on the fetus. I believed it was true, and I think he doubted it. Anyway, he altered what I had written, and I took offence.

It was then that I turned to the $B M \mathcal{F}$, of which Hugh became editor in 1947. There were two opportunities for us to meet in the late 1930s or early 1940s. Firstly, I had been asked by Charles Hill (the secretary of the BMA) to make a statistical inquiry into the workload of general practitioners and the income of private consultants (for the setting up of the NHS). I would have frequently gone to see him in BMA House. Secondly, Hugh, his wife, Kyra, and his sister Mary came to live in the small village in which I had settled in 1936. They were there from 1945 to 1961 , and we travelled together by train from Great Missenden to Euston Square on the London Metropolitan Railway.

Hugh Clegg

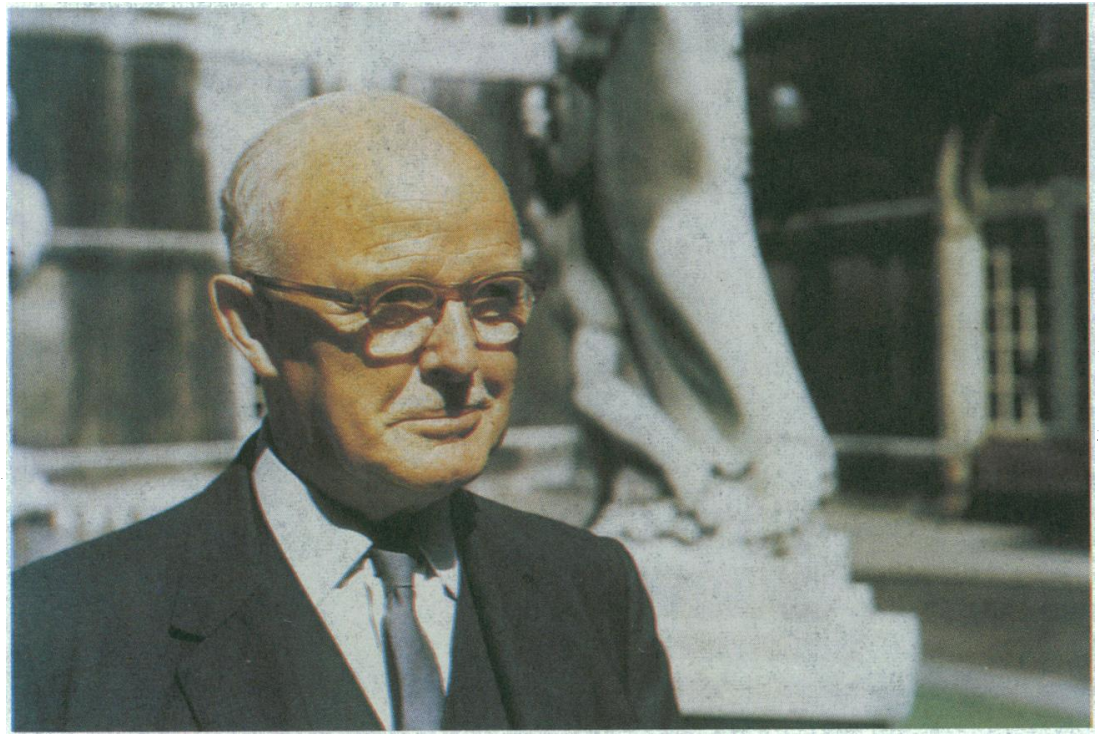

\section{0s}

- 1952: The age of tranquillisers begins with the introduction of chlorpromazine by Delay and Deniker. The "minor tranquillisers" of the benzodiazepine group were to follow soon afterwards

- 1953: James Watson and Francis Crick establish the double helical structure of DNA

- 1953: John H Gibbon Jr uses a heart-lung machine in heart surgery

- 1956: Large scale trial of birth control pills

- 1957: Discovery of interferon by Alick Isaacs and Jean Lindenmann

It was then that our mutual interests came neatly together. Hugh wanted good scientific papers for the kind of $B M \mathcal{F}$ that he wanted to create. I wanted a journal with a wide circulation among doctors-not only the scientifically minded but also the general "run of the mill" doctors. So we "clicked;" how successfully is shown in the preface of my book, Statistical Methods in Clinical and Preventive Medicine. Having thanked various authors and editors for permission to publish the various papers that I had put together on my retirement in 1961, I concluded, "Finally my gratitude to the Editor of the $B M \mathcal{F}$ calls for a sentence to itself since as many as 14 of the 25 papers here presented first appeared in its pages."

I had "fed him" with the Medical Research Council's report on the randomised trial of streptomycin in the treatment of tuberculosis (which had wide publicity in the United States as well as the United Kingdom), the trials of cortisone and aspirin in rheumatoid arthritis (with Sir Henry Cohen as chairman of the committee of leading rheumatologists), and, in the preventive field, the Medical Research Council's trial of the whooping cough vaccine (published in the $B M \mathcal{F}$ in 1951) with Professor Samuel Bedson, FRS, as chairman of the council's committee. Those are enough to show that I fulfilled my side of the concordance. Hugh filled his with a skilfully edited and presented $B M \mathcal{F}$ with an expanding circulation at home and abroad. I believe that the circulation of paying subscribers exceeded the free distribution to members of the BMA.

\section{Firm friends}

In all these contacts we became firm friends. Hugh was a joy to work with - he never took things seriously with me, and we joked, told stories (clean and not so clean), and made satirical comments on people, particularly the pompous or pretentious. In Little Kingshill he often came in for a drink (and vice versa). Kyra looked after the house and Mary the garden. Hugh I suspect, like Gallio, "cared for none of these things." My wife was very houseproud, and I think that Hugh realised this and that she might be critical of him. His response was typical. For the annual cocktail party he gave for friends of the journal women could, and would, be admitted in their own right-for example, Dame Janet Vaughan - but the only wives admitted were the editor's and that of the chairman of 


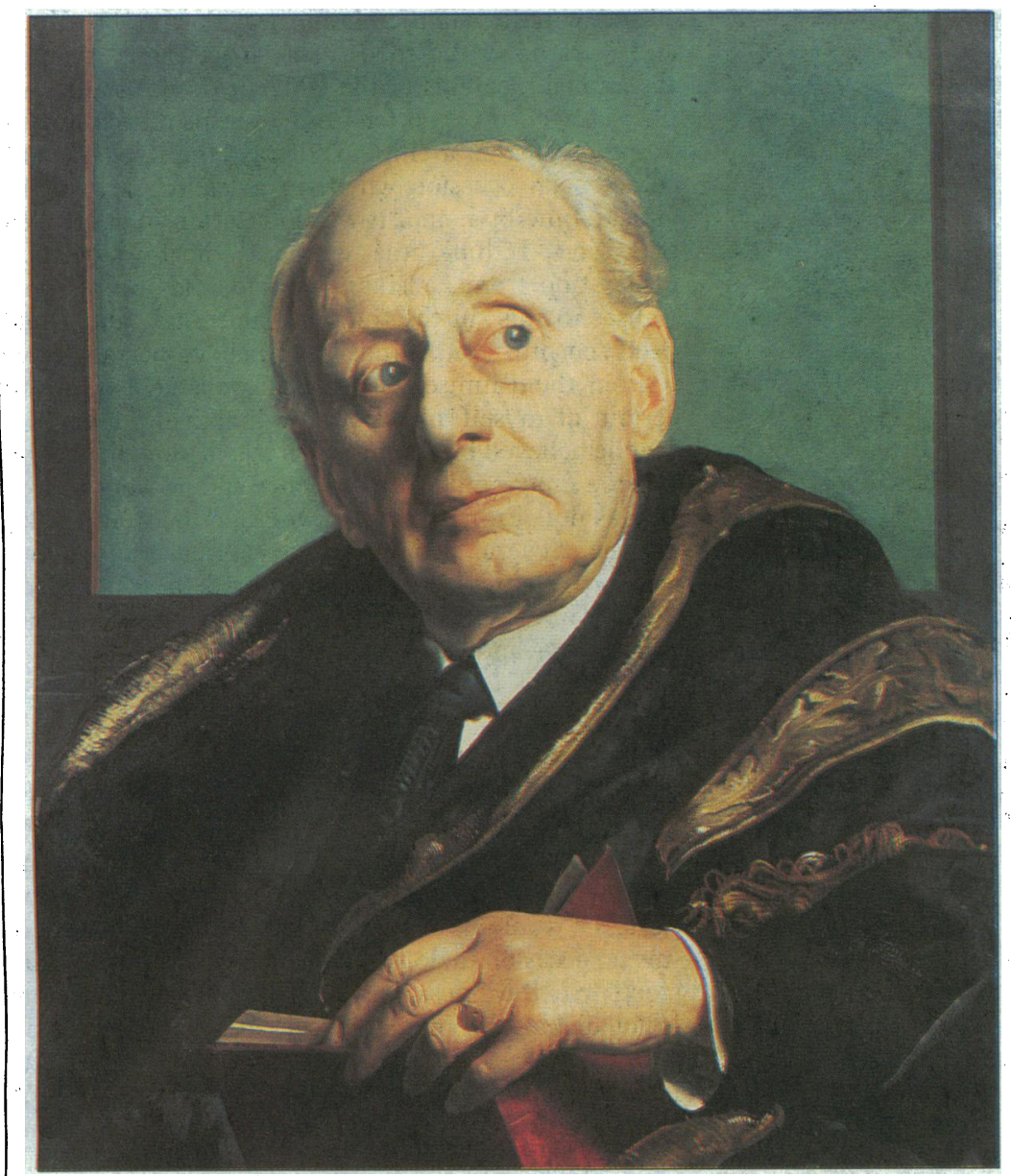

\section{Lord Moran (1950)}

\section{Pietro Annigoni (1910-69)}

When Lord Moran relinquished the presidency of the Royal College of Physicians in 1950, an office he held for nine years, the fellows decided to commission a portrait. The choice of artist was left to him, but from the beginning he knew exactly what he wanted. The likeness had to be strong and lively without being a mere photographic image. A small portrait of Lady

Howard de Walden by the then little known Italian artist Pietro Annigoni caught his eye and he decided that this was the artist for him. Lady Moran, who had helped in the search, agreed. It was a courageous choice and one that proved to be brilliant.

Nowadays Annigoni is a household name - his portrait of the youthful Queen Elizabeth II set the seal on his reputation - but in 1950 he was known only to a few critics and connoisseurs who had admired a self portrait shown at the 1949 Summer Exhibition at the Royal Academy. It is as a potraitist that he is best known in this country, although he would probably have preferred to be remembered for his religious and allegorical subjects. Always fascinated by technical problems, his favourite medium was oil-tempera as used by the Venetian painters of the High Renaissance-a happy choice for a confirmed anti-modernist. Unfortunately the quality of Annigoni's output tends to be uneven, often hard, and excessively mannered, and it has attracted some harsh criticism. At his best, however, as in the Moran portrait, he can display astonishing virtuosity. As Professor Richard Lovell tells us in his forthcoming biography of Moran, the portrait took more than 40 sittings to complete, and as Annigoni spoke no English and Moran no Italian communication was difficult; Lady Moran acted as interpreter-French being the common language. Annigoni regretted the language barrier as the only opinion he formed of his sitter was that he was rather vain. The vanity is there for all to see-in the tilt of the head and the compression of the lips. The overall impression, however, is of a powerful personality not lacking in humour. If Moran seems a little shrivelled-perhaps not as upright and strong as he would have wished-could this have anything do with his continually falling asleep during the sitting?

Perhaps the neurologist Sir Francis Walshe's muttered comment on first seeing the portrait, "Toad of Toad Hall," is not all that far from the mark.

\section{CLASSIC OF THE DECADE}

1953: F MacFarlane Burnet's Natural History of 'Infectious Disease. Cambridge: Cambridge University Press. the BMA's journal committee-Hugh added my wife.

This party brings back another memory. I told Hugh that sometimes at the annual party I was talking to a person and I was sure that I knew him well but I could not think of his name. "I can deal with that," said Hugh, "I will provide name labels on a safety pin they can pin to the lapel of their coat." This he did, and I had to tell him that he had made my situation much worse. When he asked how I replied, "Well, with no label I could scout around with questions and talk on different subjects and might thereby get a clue to the name I wanted. But I have to put on my glasses to read your name label, and that immediately betrays my ignorance:" At this he laughed immoderately and enjoyed my dilemma.

Another piece of nonsense that we enjoyed was this. In the 1950 s I had an incredible workload. I was professor of medical statistics and head of the department (statistics and epidemiology) in the London School of Hygiene and Tropical Medicine; honorary director of the Medical Research Council's statistical research unit; a member of the council itself and of many of its research committees; dean of the school; honorary secretary and president of the Royal Statistical Society; and (not necessarily all at the same time) president of the section of epidemiology of the Royal Society of Medicine and president of its section of occupational health and one of the two United Kingdom representatives on the research advisory committee of the World Health Organisation in Geneva. Under me I had some seven or eight senior research workers and some 20 numerical and secretarial staff, and I had to supervise and look after the interests of the lot. To cope I had to do a four day week in the school and work at home on Saturdays and one week day. This weekday Hugh nicknamed "doing a Bradford." He would say, "next week I am going to do a Bradford." But he took the dog for a walk or pottered around in his garden. I may here do him an injustice for I did a great deal of thinking about my research problems doing precisely those things. They called for no intelligence and provided the freedom to think, and he may have done the same with the BMF. I just do not know.

\section{Abstracts and the current rules for authors}

There was one point concerning scientific statistical papers on which Hugh agreed to my plea: that they should have a relatively long summary (or abstract). He knew as well as I did that most readers of the $B M F$ that he was creating were not going to read all of the tables of results - for example, in the articles on cancer of the lung. The summary should therefore be a précis of the paper and include a reference to every point of any substance. I assured him that this would not lengthen my articles as I went over them and eliminated every unnecessary adjective and adverb and put a short word for any long ones: That improved the papersand I did put a great deal of work into writing them. Incidentally, at the time of writing I looked at the current issue of the $B M F-N o v e m b e r 1989-$ for its "Instructions to Authors." I disagree with some of them, and I think that Hugh would have.

Firstly, the instructions say that "Tables should be simple and should not duplicate information given in the text." Certainly, tables should be simple, but it may be necessary to put in the text the most important information in the table. Thus in my article on lung cancer that was published some 40 years ago one of the tables gave detailed comparison of the jobs held by the patients and the controls. The most important result was that the number of patients who had worked in motor garages (as mechanics or pump fillers) was nearly equal to the number who had worked as 


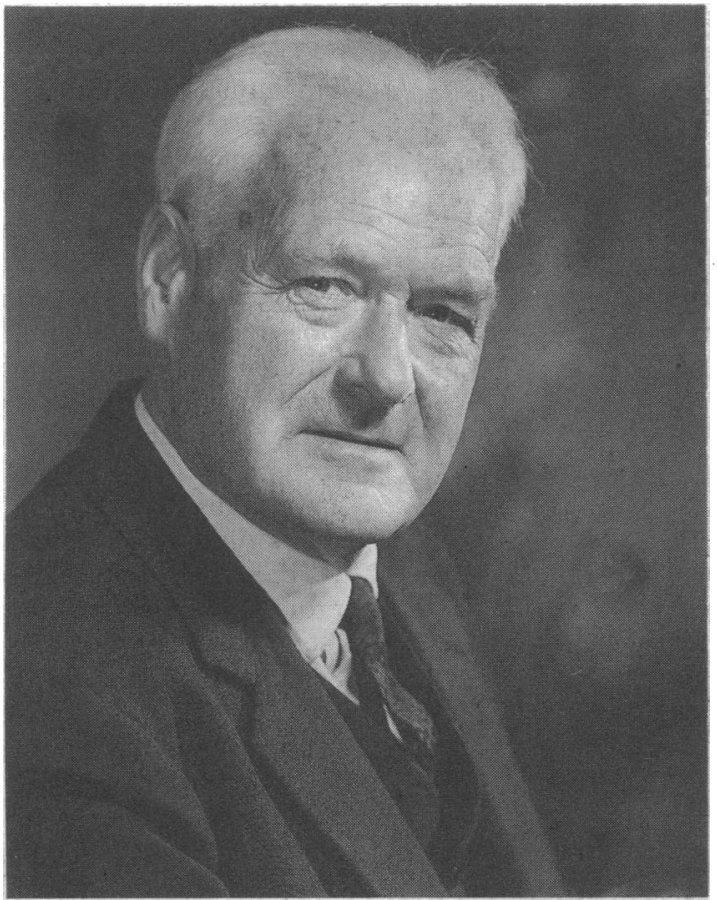

Sir Austin Bradford Hill

policemen who may have spent time on point duty in the middle of traffic. This equality gave no support to the argument that the modern increase in cancer of the lung is due to air pollution by motor cars, and that fundamental point needed repetition in the summary.

Secondly, the instructions say that "the editor reserves the customary right to style and if necessary shorten material accepted for publication." If the author cannot write clear and grammatically correct English, of course, I agree. But if he or she can then changes should be submitted to the author, who may prefer to withdraw the paper (vide my experience with Fox). I don't know whether Hugh would agreecertainly if he had changed and published an article and the author wrote a letter of protest he would have published the letter.

Thirdly, I doubt whether 150 words would invariably cover my summaries. Hugh had a saying - if I asked how long should a paper be he replied "as long as it has interest, stop when it has not."

\section{Disputes and admiration}

Hugh was rude not only to leading members of the BMA. My memory tells me that once he insulted the editor of The Times (the "Thunderer," as Trollope called it). The reason was that some reader wrote to say that he had smoked for many years and was it any good stopping after all that time? The answer was not what the media wants-yes or no, black or white-it was grey. We had evidence (rather to my surprise) that stopping smoking might be of value, but we did not have enough evidence to answer categorically. The Times did not publish a reply stating this, and Hugh, on hearing so, stepped in and wrote in the $B M F$ "Seeing that The Times is unable to find room for an answer to a question raised in its own columns, the $B M \mathcal{F}$ will do so." And he printed it. Conceivably this might have led to fewer references to papers in the $B M 7$ in The Times.

One of Hugh's close friends, whom he greatly admired, was Dr Joseph Garland of the United States, who was editor of the New England Fournal of Medicine. Joe had made that journal into one that had national and international standing - as Hugh had done with the $B M \mathcal{F}$. Joe and his wife, Myra, came to say with Hugh in Little Kingshill, and another time they stayed with my wife and me. He was a delightful person. We stayed with them in their home near Boston, but Hugh and Kyra never did so. In fact, apart from attending the annual meetings of the BMA, I do not think that Hugh travelled very often until after his retirement.

Finally, in this attempt to portray Hugh's character I come to an occasion when, in a leading article, he attacked me by name. It was in relation to controlled trials and, I think, the World Medical Association declaration from Helsinki. He had told me of some clauses in this (in the train one morning), and I had been scornful (with hindsight I believe he may have written them himself and I may well have been too certain of myself and rude). Alternatively it may be that he believed that some of his critics thought that he was too much under my influence and he would show he was not. Either way I knew Hugh too well to take offence. Several people did take offence and wrote letters to protest, which, of course, he published. Neither of us regarded it as having any bearing on our friendship - and it never did.

\section{Honest and brave}

In conclusion, Kyra, his widow, said to me over the telephone, "Hugh regarded you as "honest and brave.", Certainly, I regarded myself as honest-I had no interest in intrigue and did not conceal my views (unless it would be tactless to disclose them when there was no occasion to do so). Brave? Well I suppose I had stood up to the illness that had prevented me qualifying in medicine and made myself a new career. And with the attacks in the press and by the cigarette manufacturers and some statisticians, such as R A Fisher in Britain and Joe Berkson of the Mayo Clinic in the United States, I had remained undisturbed. I once said to Hugh that there is no use in writing letters and arguing with them - the only answer is to continue with the research and produce new evidence to prove your case and refute them. But Hugh might have added a qualification. I am not sure what word I needpossibly "indecisive," but I don't think it is quite that. It was - although I may not have shown it - that I was always doubtful of my own powers to fulfil the needs of the situation; I did not think that I could succeed Major Greenwood as professor when I had no medical qualification and understood no algebra. It was only with experience that I learned that there were assets with the school's classes-I understood the students' difficulties because I found the work difficult, Major Greenwood did not because he found it all so easy. I did not think I would be a good chairman of a committeeof the Medical Research or the World Health Organisation-but with experience I found that I was good at it - I could listen, sum up, and lead the committee to a rational conclusion. And so on.

I would have said that Hugh was honest and brave but tactless. He was clearly honest; he was brave enough to risk being sacked for his open criticisms of the BMA's "political" leaders. But I think he was tactless in his attacks on the leaders; he could have proved his complete freedom as an editor without personal attacks. In this he differed from Fox at the Lancet. Fox criticised the government's policy and the ministers' policy, but he did not make it personal, and he attempted, I think, to put forward alternatives. I don't think that Hugh did. And this is why-I would guess - that Fox got a knighthood and Hugh did not. He earned it just as much, but you can't quarrel with individuals in BMA House and Whitehall and be so rewarded.

I saw no signs in him that he regretted having put all of his life into the $B M F$ (and the special journals). He might have regretted having no outside hobby, but if he did he did not show it, and in retirement he went on 
editing and did a fine job in creating Tropical Doctor at the Royal Society of Medicine (so I am told by my close friend Alan Woodruff). Kyra said that the only regret he ever had was that, being the seventh child of a parson in Suffolk, he could not make a career in clinical medicine-at that time it was impossible to climb that ladder without money.

In short, we both made careers in ways we had not intended. In epidemiology I had learned enough medicine (and as a patient all those years earlier) to talk to him as a doctor; he had learned enough epidemiology to recognise its value and its methods. Maybe it was partly this that brought us to a mutual understanding and to a friendship that now, at least 30 years later, I look back on with great pleasure, and with great pleasure write down these recollections of a really great editor. Hugh, did you remember in the 1980s the student who had to write an essay on the three subjects - divinity, nobility, and chastity - and did so in 11 words:

“'My god,' said the Duchess, 'take your hand off my knee."”

\section{A toast to the $B M \mathcal{F}$}

continued from page 743

first contributor, Lord Platt, also initiated "Materia Non Medica" on 4 October 1975 with a piece about the surgeon Arthur MacNulty, whom he had discovered was related to Hester Piozzi (Mrs Thrale). Devoted to matters whose sole connection with medicine was that they were discussed by doctors, these occupied a proud page of the journal for some years until relegated (as were "Any Questions?") to the ignominious stature of fillers-and it shows.

A few years later another momentous first arose through contact with Elizabeth Brain, a medical artist and wife of Michael Brain, a haematologist in Canada and son of Lord Brain. This was the remarkable ABC series of illustrated articles, which began in 1978 with an ABC of Ophthalmology by P A Gardiner. Mistressminded (quite rightly we are not allowed to be male chauvinist in the $B M \mathcal{F}$ ) by Jane Smith of the editorial staff, the series'may be said to have started changes in design and typography, with an emphasis on illustrations (known in the trade as "pics"), which have been widely acclaimed. Ten years on we have an Economist look-alike that has won an award but has been received by doctors, who on the whole don't like change, with mixed reactions.

An important feature of the journal from 1892 was the epitome of current published work, many pages of abstracts from journals around the world occupying the back of each issue. They were killed off by the last war but were subsequently published by Hugh Clegg from 1947 to 1971 as a separate journal called Abstracts of World Medicine. They provided welcome pocket money -10 shillings $(50 \mathrm{p})$ if memory serves -for impecunious registrars who cared to translate from French, German, or Italian. This seeming diversion is designed to show that apparent novelties are often variations on an old theme: thus the spicy comments on articles from current journals started by Minerva in
October 1976. With Minerva's column being arguably a more popular item than the obituaries, the $B M \mathcal{F}$ must be the only journal that has to be read backwards. Minerva's identity is a closely guarded secret; rumour has it that the original wager of a fiver still stands.

\section{An appreciation}

Over 100000 copies of the $B M \mathcal{F}$ are printed each week; a third of them go abroad. It is read by laypeople, students, doctors of all specialties, and other health professionals. I was given copies as a schoolboy in the 1930s by our family doctor, John Thwaites, a keen BMA man and later a deputy editor of the journal. It used to be available on W H Smith's bookstalls on Fridays, but I haven't spotted it recently, perhaps because it is now deemed too specialised and costs $£ 4.10$ a copy. Repeatedly I hear complaints from individual doctors that it no longer caters to their needs, but I suspect that a poll would confirm its continuing popularity and that it still fulfils its original aim "to educate, inform and entertain." Its great merit is that it has something for everyone: like with a favourite newspaper one thumbs through the pages sampling titbits of information.

If reading is a pleasure writing for the $B M \mathcal{F}$ carries a special cachet and puts the author in touch with doctors throughout the world. Aspiring writers may like to know that the journal is particularly generous in supporting its authors. I submitted an unsolicited editorial (never do that) as a keen young registrar in 1953 and have had journalistic work put my way ever since. My belief is that the journal will adapt, as it constantly has in the past, to whatever changes the future has in store and will triumphantly celebrate its bicentenary in 2040 .

1 Waksman BH. Information overload in immunology. Possible solutions to the problem of excessive publication. I Immunol 1980;124:1009-15. 2 Medawar PB. Is the scientific paper fraudulent? Saturday Review 1964;47:42. (For comment see Br Med $\mathcal{F}$ 1965;ii:868-9.) 